\title{
Effect of $\mathrm{Pt} / \mathrm{Pd}$-doped $\mathrm{TiO}_{2}$ on the photocatalytic degradation of trichloroethylene
}

\author{
Hsin-Hung Ou, Shang-Lien Lo* \\ Research Center for Environmental Pollution Prevention and Control Technology, Graduate Institute of \\ Environmental Engineering, National Taiwan University, 71 Chou-Shan Rd., Taipei 106, Taiwan, ROC
}

Received 5 March 2007; received in revised form 26 May 2007; accepted 29 May 2007

Available online 7 June 2007

\begin{abstract}
Photocatalytic degradation of trichloroethylene (TCE) over Pt/Pd-doped $\mathrm{TiO}_{2}$ was conducted to investigate the effect of Pt and Pd on the TCE degradation and on the yields of dichloroacetyl chloride (DCAC) and phosgene. In the presence of Pt and Pd, the degradation of TCE was retarded; especially $\mathrm{Pd}$ had a significantly negative effect on TCE degradation, which was ascribed to the intercalation of $\mathrm{Pd}$ into the lattice of TiO $\mathrm{M}_{2}$. Moreover, Pt had no influence on the selectivity toward DCAC and phosgene while the selectivity toward phosgene in the presence of Pd was enhanced. As for the behavior of $\mathrm{Pt}$ and $\mathrm{Pd}$ in TCE degradation, $\mathrm{Pt}$-doped $\mathrm{TiO}_{2}$ exhibited the same photocatalytic behavior as $\mathrm{P} 25 \mathrm{TiO}_{2}$ whereas $\mathrm{Pd}-\mathrm{doped}$ TiO 2 led to a different photocatalytic mechanism.
\end{abstract}

(C) 2007 Elsevier B.V. All rights reserved.

Keywords: Metal-doped $\mathrm{TiO}_{2}$; Trichloroethylene

\section{Introduction}

Photocatalysis has been a promising and significant prospect for environmental purifications where it is confirmed that the photocatalytic potential is subject to the recombination of generated photoelectrons and photoholes. To improve the photocatalytic efficiency in this regard, many studies have conducted a variety of modifications aimed at the crystal structure, specific surface area, doping species, surface hydroxyl group and so on. Among these modifications, metal doping has been found to enhance the photocatalytic performance efficiently and to change the photocatalytic mechanism. Such enhancement is ascribed to several origins. Firstly, the formation of Schottky barrier at the interface of metals and $\mathrm{TiO}_{2}$ improves the separation of holes and electrons. Secondly, the holes act as a sink for electrons to prevent the accumulation of excess electrons on the surface of $\mathrm{TiO}_{2}$. Thirdly, the defect sites $\left(\mathrm{Ti}^{3+}\right)$, which are responsible for the potential of photocatalysis, can be enhanced by some metal particles. However, the reported doped metals do not always have a positive effect on the improvement of pho-

\footnotetext{
* Tel.: +886 223625373; fax: +886223928830.

E-mail address: sllo@ntu.edu.tw (S.-L. Lo).
}

tocatalytic efficiency and the role of doped species in reaction mechanism is far more complex than being a simple electron sink [1-4].

Trichloroethylene (TCE), a well-known volatile organic compound, has been applied to various industrial uses such as degreasing and dry cleaning. Such applications of TCE have become one of the major concerns in environmental pollution. Photocatalytic oxidation of TCE has been confirmed as an efficient treatment, and Dibble and Raupp [5] first reported the photocatalytic oxidation of TCE over $\mathrm{TiO}_{2}$. Subsequent studies have revealed the degradation behavior of TCE in terms of reaction conditions and the degradation mechanism has also been well explained [6-17]. In general, photocatalytic degradation of TCE over $\mathrm{TiO}_{2}$ produces two major by-products, dichloroacetyl chloride (DCAC) and phosgene, along with trace amounts of pentachloroethane $\left(\mathrm{C}_{2} \mathrm{HCl}_{5}\right)$, oxalyl chloride $(\mathrm{COClCOCl})$, and monochloroacetic acid $\left(\mathrm{CH}_{2} \mathrm{ClCOOH}, \mathrm{MCAA}\right)$. However, little attention has been paid to the effect of metal-doped $\mathrm{TiO}_{2}$ on photocatalytic degradation of TCE. Driessen and Grassian [2] investigated the photocatalytic oxidation of TCE over $\mathrm{Pt} / \mathrm{TiO}_{2}$, and discovered that $\mathrm{Pt}$ species retards the degradation of TCE. Park et al. [3] have also tested several types of doped metal, and concluded that the high valence cations $\left(\mathrm{Mo}^{5+}, \mathrm{Nb}^{5+}\right.$, and $\left.\mathrm{W}^{6+}\right)$ improved TCE degradation owing to the relatively high amount 
of adsorbed hydroxyl group. The effect of $\mathrm{Cr}, \mathrm{Fe}, \mathrm{Ni}, \mathrm{Cu}, \mathrm{Pt}$ and $\mathrm{Ca}(\mathrm{OH})_{2}$ on the formation of DCAC, phosgene, and chloroform was also investigated by Tanimura et al. [4], showing that the by-products from photocatalytic degradation of TCE could be suppressed by the addition of $\mathrm{Cu}$ and $\mathrm{Ca}(\mathrm{OH})_{2}$. Therefore, the present study attempted to examine TCE degradation over $\mathrm{Pt} / \mathrm{Pd}$-doped $\mathrm{TiO}_{2}$. The yields of DCAC and phosgene were also measured to investigate the effect of Pd and Pt on the selectivity toward DCAC and phosgene. A plausible mechanism of TCE degradation in the presence of $\mathrm{Pt} / \mathrm{Pd}$ species was also proposed.

\section{Experiment}

\subsection{Preparation of Pt-doped $\mathrm{TiO}_{2}$ and $\mathrm{Pd}$-doped $\mathrm{TiO}_{2}$}

The modified $\mathrm{TiO}_{2}$ were prepared by the impregnation method. $600 \mathrm{mg} \mathrm{TiO}_{2}$ (Degussa P25) were stirred in a series of concentrations of $\mathrm{H}_{2} \mathrm{PtCl}_{6}$ and $\mathrm{PdCl}_{2}$ solutions at $373 \mathrm{~K}$ for $60 \mathrm{~min}$. Afterward, the resulting $\mathrm{Pt}^{4+} / \mathrm{TiO}_{2}$ and $\mathrm{Pd}^{2+} / \mathrm{TiO}_{2}$ slurries were dried in a vacuum freeze-dryer for $20 \mathrm{~h}$ (100-200 mTorr at $-57.5^{\circ} \mathrm{C}$ ). Pt-doped $\mathrm{TiO}_{2}$ and Pddoped $\mathrm{TiO}_{2}$ samples were obtained in the tubular oven under the atmosphere of $20 \% \mathrm{H}_{2} / 80 \% \mathrm{~N}_{2}$ at progressively elevated temperatures for $3 \mathrm{~h}\left(30,120\right.$, and $\left.400^{\circ} \mathrm{C}\right)$. The as-prepared Ptdoped $\mathrm{TiO}_{2}$ and $\mathrm{Pd}$-doped $\mathrm{TiO}_{2}$ were exposed to the air for 3 $\mathrm{hr}$ before further characterizations, an exposure period similar to that during the kinetic experiments. In the following passages, Pt-doped $\mathrm{TiO}_{2}$ and $\mathrm{Pd}$-doped $\mathrm{TiO}_{2}$ reduced at $400^{\circ} \mathrm{C}$ is abbreviated as $\mathrm{Pt} / \mathrm{TiO}_{2}$ and $\mathrm{Pd} / \mathrm{TiO}_{2}$, respectively.

\subsection{Characterization of Pt-doped $\mathrm{TiO}_{2}$ and $\mathrm{Pd}$-doped $\mathrm{TiO}_{2}$}

BET specific surface areas $\left(S_{\mathrm{BET}}\right)$ of the samples were measured by an automated gas adsorption analyzer (Micromeritics ASAP 2010). X-ray diffraction (XRD) with the scan range of $20-80^{\circ}$ was employed to determine the crystalline phase of the modified $\mathrm{TiO}_{2}$ powders. X-ray photoelectron spectroscopic (XPS) analysis was carried out on a spectrometer equipped with a $\mathrm{Mg}(\mathrm{K} \alpha) \mathrm{X}$-ray source. All binding energies were referenced to the $\mathrm{C} 1 \mathrm{~s}$ peak at $284.6 \mathrm{eV}$, which is invariably present on the film surface. The spectra were fitted by XPSPEAK with a linear background and to $80 \%$ Gausssian/20\% Lorentzian peak shape. The standard procedure of temperature programmable reduction (TPR) measurements involved purging the reactor with $\mathrm{He}$ gas for $30 \mathrm{~min}$, and heating the powders at $150{ }^{\circ} \mathrm{C}$ for $60 \mathrm{~min}$ to remove the impurities and water adsorbed on the surface of modified $\mathrm{TiO}_{2}$. The resulting powders were subsequently reduced by a mixing gas of $90 \% \mathrm{Ar} / 10 \% \mathrm{H}_{2}$ at $40 \mathrm{ml} \mathrm{min}^{-1}$ and a temperature ramping rate of $10^{\circ} \mathrm{C} \mathrm{min}^{-1}$ from 25 to $600^{\circ} \mathrm{C}$. The structure of anatase $\mathrm{TiO}_{2}$ demonstrated in the manuscript was constructed by the Ca.R.Ine version 3.1 crystallography program package.

\subsection{Photocatalytic tests}

Batch experiments of photocatalytic degradation of TCE were conducted in a flat-plate photoreactor (FPPR). This reac- tor was made of stainless steel with a volume of $2 \mathrm{~L}(L=20 \mathrm{~cm}$, $W=10 \mathrm{~cm}$, and $H=10 \mathrm{~cm})$, both ends to which silica wafer was adhered to avoid emission. The detail was described in our previous publication [17]. $\mathrm{TiO}_{2}$, Pt-doped $\mathrm{TiO}_{2}$, and $\mathrm{Pd}$ doped $\mathrm{TiO}_{2}$ samples supported on silica board of $120 \mathrm{~cm}^{2}$ were prepared by the dip-coating method with a normalized concentration of $0.83 \mathrm{mg} \mathrm{cm}^{-2}$. For a typical run, the initial concentration of TCE was $67.7 \pm 5 \mu \mathrm{M}$, and the relative humidity and oxygen concentration were kept at $25 \pm 2.5 \%$ and $3.53 \mathrm{mM}$, respectively. The reactor was wrapped with a heating tape to maintain a temperature of $308 \mathrm{~K}$. Illumination was provided by three $8 \mathrm{~W}$ black-light fluorescent lamps, principally emitting a light $365 \mathrm{~nm}$ in wavelength with an intensity of $2.34 \pm 0.23 \mathrm{~mW} \mathrm{~cm}^{-2}$. TCE, DCAC, and phosgene were quantified under a series of time sequence via manual injection into a gas chromatograph (5890II) equipped with a flame ionization detector. The photocatalytic ability of doped $\mathrm{TiO}_{2}$ was surveyed by the observed rate constant $\left(k_{\mathrm{obs}}\right)$ of TCE degradation based on the pseudo-first-order reaction.

\section{Results and discussion}

\subsection{Specific surface area and XRD analysis}

No significant change in $S_{\mathrm{BET}}$ was observed among the modified $\mathrm{TiO}_{2}$ samples and the values fell into the range of $47-52 \mathrm{~m}^{2} \mathrm{~g}^{-1}$. Compared to the $S_{\mathrm{BET}}$ of $\mathrm{P} 25 \mathrm{TiO}_{2}$ $\left(52.5 \mathrm{~m}^{2} \mathrm{~g}^{-1}\right)$, a slight decrease with increasing loading amounts of Pt and Pd was found. The phenomenon can be attributed to the aggregation of $\mathrm{TiO}_{2}$ after thermal treatment and the blocking of fine capillaries of the parent $\mathrm{TiO}_{2}$ surface by metal islands. Moreover, neither $\mathrm{Pt} / \mathrm{TiO}_{2}$ nor $\mathrm{Pd} / \mathrm{TiO}_{2}$ presented obvious change in XRD spectra (Fig. 1). This result can presumably be ascribed to the combinations of low contents of doping Pt or Pd, small particle size, and homogeneous distribution.

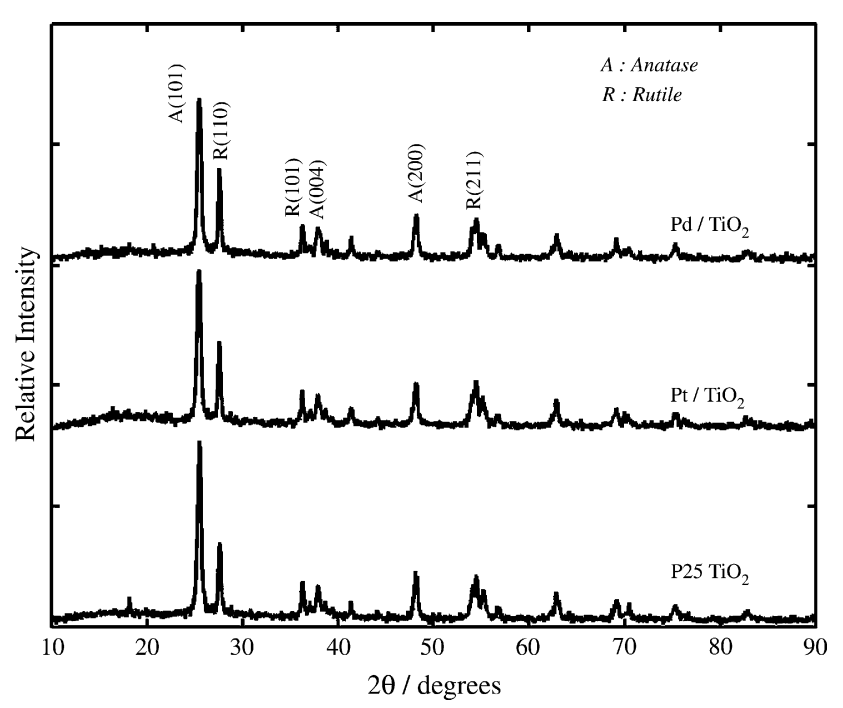

Fig. 1. The XRD patterns of $\mathrm{P} 25 \mathrm{TiO}_{2}, 0.1 \mathrm{wt} . \% \mathrm{Pt} / \mathrm{TiO}_{2}$ and 0.04 wt.\% $\mathrm{Pd} / \mathrm{TiO}_{2}$. 


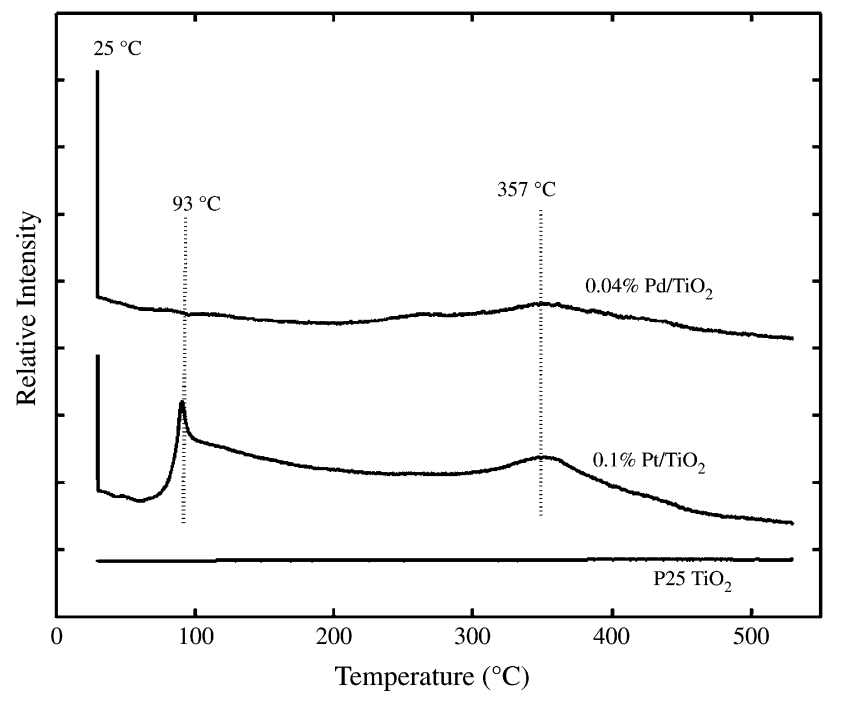

Fig. 2. The TPR spectra of $\mathrm{P} 25 \mathrm{TiO}_{2}, 0.1 \mathrm{wt} . \% \mathrm{Pt} \mathrm{TiO}_{2}$ and 0.04 wt. $\% \mathrm{Pd} \mathrm{TiO}_{2}$.

\section{2. $T P R$}

Fig. 2 demonstrates TPR spectra concerning the reduction scenario of $\mathrm{K}_{2} \mathrm{PtCl}_{4}$ and $\mathrm{PdCl}_{2}$. No significant peak for pure $\mathrm{TiO}_{2}$ was observed in the temperature of interest ranging from 25 to $600{ }^{\circ} \mathrm{C}$. In the case of the representative Pt-doped $\mathrm{TiO}_{2}$, the TPR profile exhibited an obvious peak at room temperature along with two other peaks at 93 and $357^{\circ} \mathrm{C}$. The phenomenon suggests the presence of three stages during the reduction process. The first peak exhibits the highest intensity, whereas the second peak amounts to one-third of the hydrogen consumption. This indicates the majority of $\mathrm{Pt}$ species is reduced to $\mathrm{Pt}^{0}$ at room temperature. The TPR spectrum of Pd-doped $\mathrm{TiO}_{2}$ presented a significant peak at $25^{\circ} \mathrm{C}$, with a vague peak at approximately $355^{\circ} \mathrm{C}$, also indicating that the $\mathrm{Pd}$ species can be reduced to $\mathrm{Pd}^{0}$ at room temperature in the presence of $\mathrm{H}_{2}$. Besides, the color of the Pt-doped $\mathrm{TiO}_{2}$ and $\mathrm{Pd}$-doped $\mathrm{TiO}_{2}$ samples changed from bright yellow and reddish to gray, respectively, suggesting that the surface species on $\mathrm{TiO}_{2}$ have been changed.

\subsection{XPS}

XPS analysis was conducted to determine the chemical and electronic structure of the as-prepared samples. The XPS spectra of $\mathrm{O} 1 \mathrm{~s}$ within $\mathrm{TiO}_{2}$ can be principally assigned to the crystal lattice oxygen $\left(\mathrm{Ti}^{4+}-\mathrm{O}\right)$ and surface adsorbed $\mathrm{OH}(\mathrm{Ti}-\mathrm{OH})$ with the binding energies of 529.8 and $531.3 \mathrm{eV}$, respectively [18]. Fig. 3( $\mathrm{a}$ and $\mathrm{b}$ ) show the deconvoluted $\mathrm{O} 1 \mathrm{~s}$ bands of $\mathrm{Pt} / \mathrm{TiO}_{2}$ and $\mathrm{Pd} / \mathrm{TiO}_{2}$, respectively, which indicate the presence of $\mathrm{Ti}^{4+}-\mathrm{O}$ and $\mathrm{Ti}-\mathrm{OH}$. As seen in Table 1, the concentration of $\mathrm{Ti}-\mathrm{OH}$ increases after the modification by $\mathrm{Pt}$ and Pd doping, suggesting the doped $\mathrm{TiO}_{2}$ enhance the formation of $\mathrm{OH}^{\bullet}$. Regarding the Ti species for $\mathrm{Pt} / \mathrm{TiO}_{2}$ and $\mathrm{Pd} / \mathrm{TiO}_{2}$, curve fitting indicated the presence of $\mathrm{Ti}^{3+}$ in addition to the dominant $\mathrm{Ti}^{4+}$ peak (Fig. 3(c)). This evidenced the existence of reduced states $\left(\mathrm{Ti}^{3+}\right)$ with the line position at $457.5 \mathrm{eV}$, while the bonding energy of $\mathrm{Ti}^{4+}$ is located at $459 \mathrm{eV}$. The formation of $\mathrm{Ti}^{3+}$ implies that the interac-
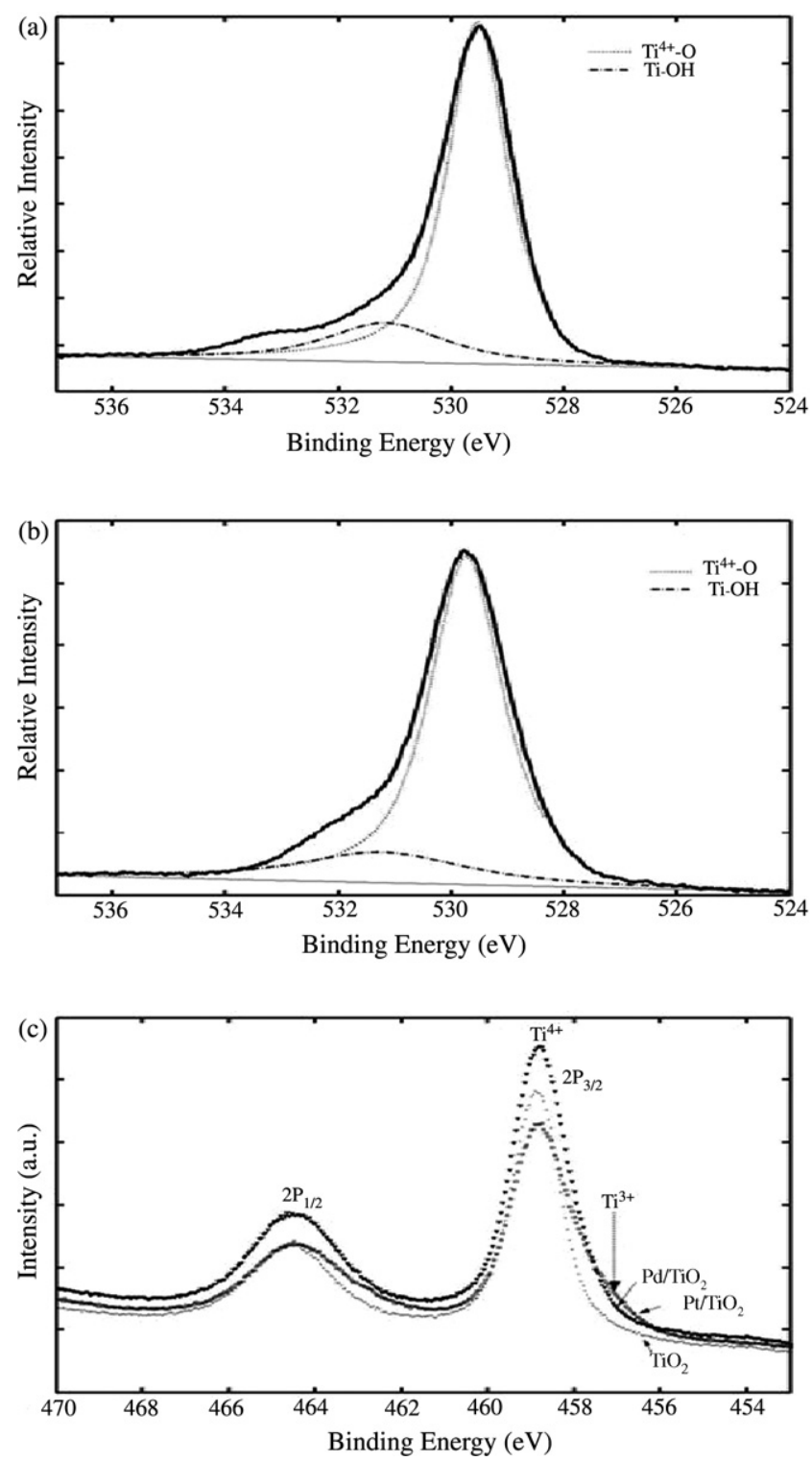

Fig. 3. The XPS spectra of (a) $0.1 \mathrm{wt} . \% \mathrm{Pt} / \mathrm{TiO}_{2}$ for $\mathrm{O} 1 \mathrm{~s}$ region, (b) $0.04 \mathrm{wt} . \%$ $\mathrm{Pd} / \mathrm{TiO}_{2}$ for $\mathrm{O} 1 \mathrm{~s}$ region and (c) $\mathrm{P} 25 \mathrm{TiO}_{2}, 0.1 \mathrm{wt} . \% \mathrm{Pt} / \mathrm{TiO}_{2}$ and $0.0 \mathrm{wt} . \%$ $\mathrm{Pd} / \mathrm{TiO}_{2}$ for Ti $2 \mathrm{P}$ region.

tion between $\mathrm{Pt} / \mathrm{Pd}$ species and $\mathrm{TiO}_{2}$ matrix occurred during the reduction reaction [19]. $\mathrm{P}^{\mathrm{II}}$ was the major species after reduction at 25 and $120^{\circ} \mathrm{C}$, while $\mathrm{Pt}^{0}$ was dominant in the case of samples reduced at $400{ }^{\circ} \mathrm{C}$ (Fig. 4(a)). This indicates that the successive reduction from $\mathrm{Pt}^{\mathrm{IV}}$ to $\mathrm{Pt}^{0}$ needs to be driven at $400^{\circ} \mathrm{C}$. As seen in Fig. 4(b), oxidation species of Pd was also observed at 25 and $120^{\circ} \mathrm{C}$, even though the TPR result demonstrated that the majority of Pd species can be reduced to $\mathrm{Pd}^{0}$ at $25^{\circ} \mathrm{C}$. In fact, there is a discrepancy in the $\mathrm{Pt} / \mathrm{Pd}$ amount between the XPS results and theoretical introduction in fabrication. This indicates that part of the introduced $\mathrm{Pt} / \mathrm{Pd}$ is not on the surface of $\mathrm{TiO}_{2}$, and suggests the intercalation of $\mathrm{Pt}$ and $\mathrm{Pd}$ into the lattice of $\mathrm{TiO}_{2}$. In addition, the peak shift was observed in the cases of $\mathrm{Pt} / \mathrm{TiO}_{2}$ and $\mathrm{Pd} / \mathrm{TiO}_{2}$, which can be ascribed to either diameter change of $\mathrm{Pt} / \mathrm{Pd}$ particles or the charge transfer from the partially reduced $\mathrm{TiO}_{x}$ to $\mathrm{Pt} / \mathrm{Pd}$ particles [20-22]. 
Table 1

Results of curve-fitting of high resolution XPS spectra for the O1s region in Pt-doped $\mathrm{TiO}_{2}$ and Pd-doped $\mathrm{TiO}_{2}$

\begin{tabular}{|c|c|c|c|c|}
\hline \multirow[t]{2}{*}{ Catalysts } & \multicolumn{2}{|c|}{ Crystal lattice oxygen $\left(\mathrm{Ti}^{4+}-\mathrm{O}\right)$} & \multicolumn{2}{|c|}{ Surface adsorbed $\mathrm{OH}(\mathrm{Ti}-\mathrm{OH})$} \\
\hline & Peak area $(\%)$ & Binding energy $(\mathrm{eV})$ & Peak area $(\%)$ & Binding energy $(\mathrm{eV})$ \\
\hline Pure $\mathrm{TiO}_{2}$ & 91.75 & 529.81 & 8.25 & 531.64 \\
\hline 0.03 wt. $\% \mathrm{Pt} / \mathrm{TiO}_{2}$ & 90.18 & 529.76 & 9.82 & 531.60 \\
\hline 0.1 wt. $\% \mathrm{Pt} / \mathrm{TiO}_{2}$ & 86.90 & 529.43 & 13.10 & 531.25 \\
\hline 0.15 wt. $\% \mathrm{Pt} / \mathrm{TiO}_{2}$ & 84.87 & 529.80 & 15.13 & 531.99 \\
\hline 0.02 wt. $\mathrm{Pd} / \mathrm{iO}_{2}$ & 92.95 & 529.91 & 7.05 & 531.59 \\
\hline 0.04 wt. $\% \mathrm{Pd} / \mathrm{TiO}_{2}$ & 90.47 & 529.68 & 9.53 & 531.68 \\
\hline 0.06 wt. $\% \mathrm{Pd} / \mathrm{TiO}_{2}$ & 88.81 & 529.77 & 11.19 & 532.15 \\
\hline
\end{tabular}

\subsection{Catalytic tests}

\subsubsection{The effect of Pt and $P d$ on TCE degradation}

Compared with $\mathrm{P} 25 \mathrm{TiO}_{2}, \mathrm{Pt} / \mathrm{TiO}_{2}$ and $\mathrm{Pd} / \mathrm{TiO}_{2}$ show poor performance in TCE degradation, as demonstrated in Fig. 5. In the case of $\mathrm{Pt} / \mathrm{TiO}_{2}$, the values of $k_{\mathrm{obs}}$ fell into the range
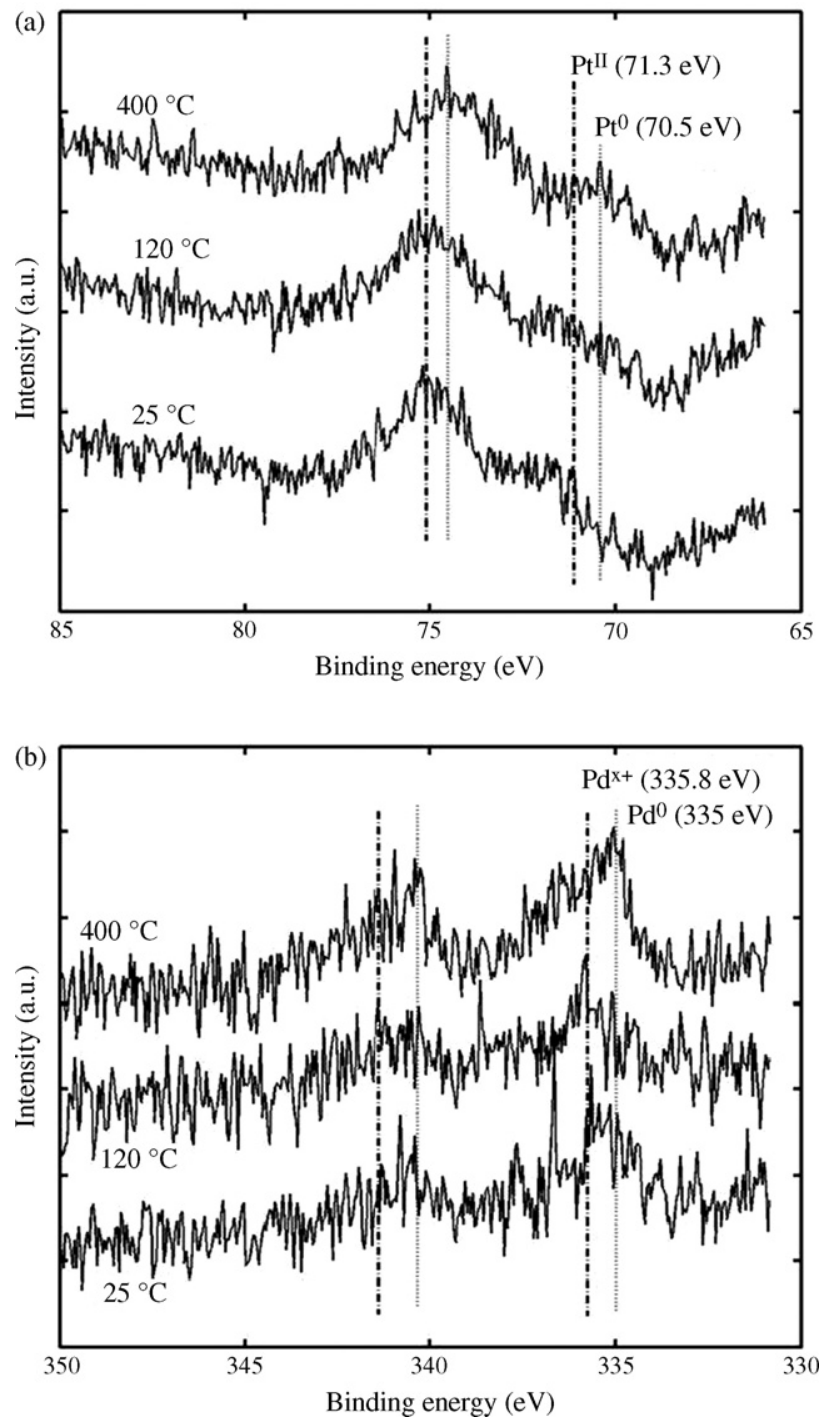

Fig. 4. The XPS spectra of (a) $0.1 \mathrm{wt} . \% \mathrm{Pt} \mathrm{TiO}_{2}$ for $\mathrm{Pt} 4 \mathrm{f}$ region and (b) $0.04 \mathrm{wt} . \%$ $\mathrm{Pd} \mathrm{TiO}_{2}$ for $\mathrm{Pd} 3 \mathrm{~d}$ region at reducing temperatures of 25,120 , and $400{ }^{\circ} \mathrm{C}$. of $(1.02-1.62) \times 10^{-2} \mathrm{~min}^{-1}$ while that of $\mathrm{P} 25 \mathrm{TiO}_{2}$ was $(1.70 \pm 0.08) \times 10^{-2} \mathrm{~min}^{-1}$. Concerning the performance of $\mathrm{Pd} / \mathrm{TiO}_{2}$, the corresponding $k_{\text {obs }}$ values fell into the range of $(0.40-0.79) \times 10^{-2} \mathrm{~min}^{-1}$, which were remarkably inferior to that of $\mathrm{P} 25 \mathrm{TiO}_{2}$. The diminished activity can be attributed to many potential origins. The deposited $\mathrm{Pt}$ or Pd clusters would reduce the opportunities for TCE to adsorb on $\mathrm{TiO}_{2}$ and would scatter the UV light to decrease the irradiation efficiency of $\mathrm{TiO}_{2}$. Another reasonable inference is that the deposited metal particles may act as the recombination center for photoinduced holes
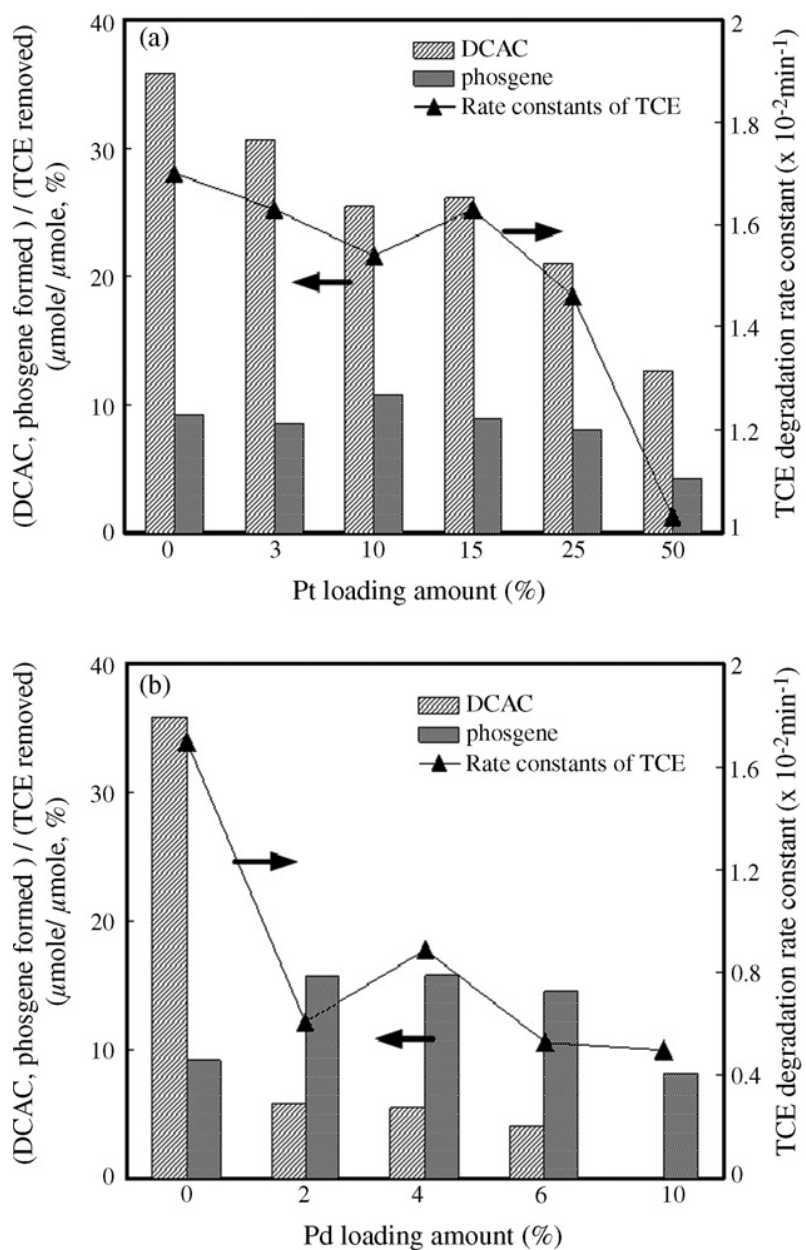

Fig. 5. The dependence of degradation rate constants of TCE, the yields of DCAC and phosgene on the loading amount of $\mathrm{Pt} / \mathrm{Pd}$ species (a) $\mathrm{Pt} / \mathrm{TiO}_{2}$ and (b) $\mathrm{Pd} / \mathrm{TiO}_{2}$. 
and electrons. The defect sites $\left(\mathrm{Ti}^{3+}\right)$ within catalysts were found to arise from the modification of Pt and Pd doping (Fig. 3(c)). However, the existence of $\mathrm{Ti}^{3+}$ does not seem beneficial to TCE degradation even though it is possible for the adsorption and photoactivation of oxygen to produce $\mathrm{O}_{2}{ }^{\bullet-}$. Driessen and Grassian [2] reported that the presence of Pt particles was detrimental to the photocatalysis of TCE owing to the blocking of $\mathrm{Ti}^{3+}$ active sites by Pt particles.

Regarding the major oxidant species in TCE degradation, some reports claimed that $\mathrm{OH}^{\bullet}[3,14]$ were responsible for TCE degradation while others preferred $\mathrm{Cl}^{\bullet}[4,6,7]$. Table 1 demonstrates that the concentration of surface adsorbed $\mathrm{OH}$ increases with increasing loading amounts of Pt and Pd. However, the degradation rate of TCE was irrelevant to the concentration of $\mathrm{OH}$, indicating that the $\mathrm{OH}^{\bullet}$ may not account for the TCE degradation. Based on O-atom isotope-label studies, Fan and Yates [23] have also suggested that the surface adsorbed water was not involved in the TCE degradation. Therefore, it is confirmed that $\mathrm{Cl}^{\bullet}$ instead of $\mathrm{OH}^{\bullet}$ are responsible for TCE degradation.

In addition, the $k_{\text {obs }}$ values of $\mathrm{Pt} / \mathrm{TiO}_{2}$ samples were higher than that of $\mathrm{Pd} / \mathrm{TiO}_{2}$ by a factor of $1.5-4$. The drastic decrease in the presence of Pd can be attributed to the intercalation of Pd into $\mathrm{TiO}_{2}$ lattice. As shown in the XRD results (Fig. 1) no separate dopant-related phase is present. This indicates the dopant $(\mathrm{Pt}$ and $\mathrm{Pd}$ ) is either dissolved within the substitution sites within the $\mathrm{TiO}_{2}$ lattice or intercalated into the octahedral sites [19]. Meanwhile, the effective ion sizes of $\mathrm{Ti}^{4+}, \mathrm{Pt}^{4+}$, and $\mathrm{Pd}^{2+}$ are 0.605 , 0.625 , and $0.86 \AA$, respectively. This suggests that $\mathrm{Pd}^{2+}$ ion is energetically favorable to going into the larger octahedral interstitial sites in the $\mathrm{TiO}_{2}$ lattice [24], as illustrated in Scheme 1. When $\mathrm{Pd}^{2+}$ ion is doped into the $\mathrm{TiO}_{2}$ lattice, the empty space within the lattice is reduced. The mobility of oxygen vacancies is then retarded and cannot reach the interior region of the $\mathrm{Pd} / \mathrm{TiO}_{2}$. Therefore, a far lower efficiency of electrons trapping for the $\mathrm{Pd} / \mathrm{TiO}_{2}$ significantly inhibits the formation of $\mathrm{Cl}^{\bullet}$ (Eq. (2)), a principal oxidation species in TCE degradation.

\subsubsection{The effect of reduction temperature of Pt/Pd species on TCE degradation}

The effect of reduction temperature of $\mathrm{Pt} / \mathrm{Pd}$ species on TCE degradation was also investigated with samples of

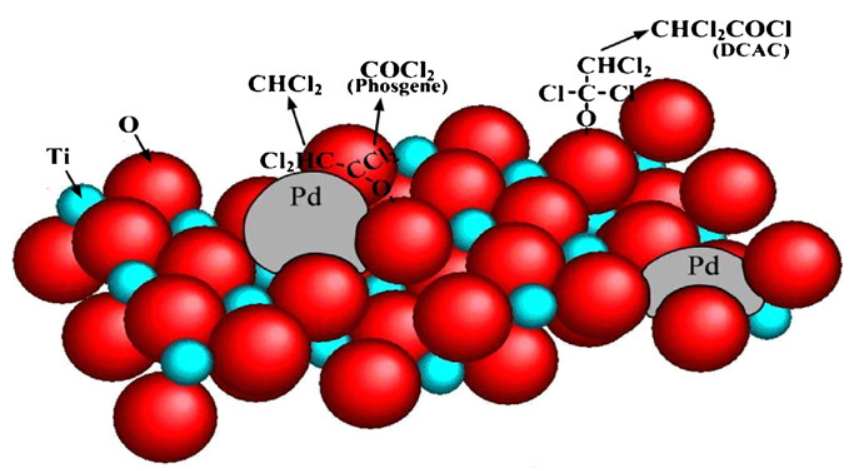

Scheme 1. $\mathrm{Pd} / \mathrm{TiO}_{2}$ surface. $\mathrm{Pd}$ species were intercalated into the lattice of $\mathrm{TiO}_{2}$ and aided the cleavage of $\mathrm{C}-\mathrm{C}$ bond within $\mathrm{CHCl}_{2} \mathrm{COCl}_{2}{ }^{\bullet}$.
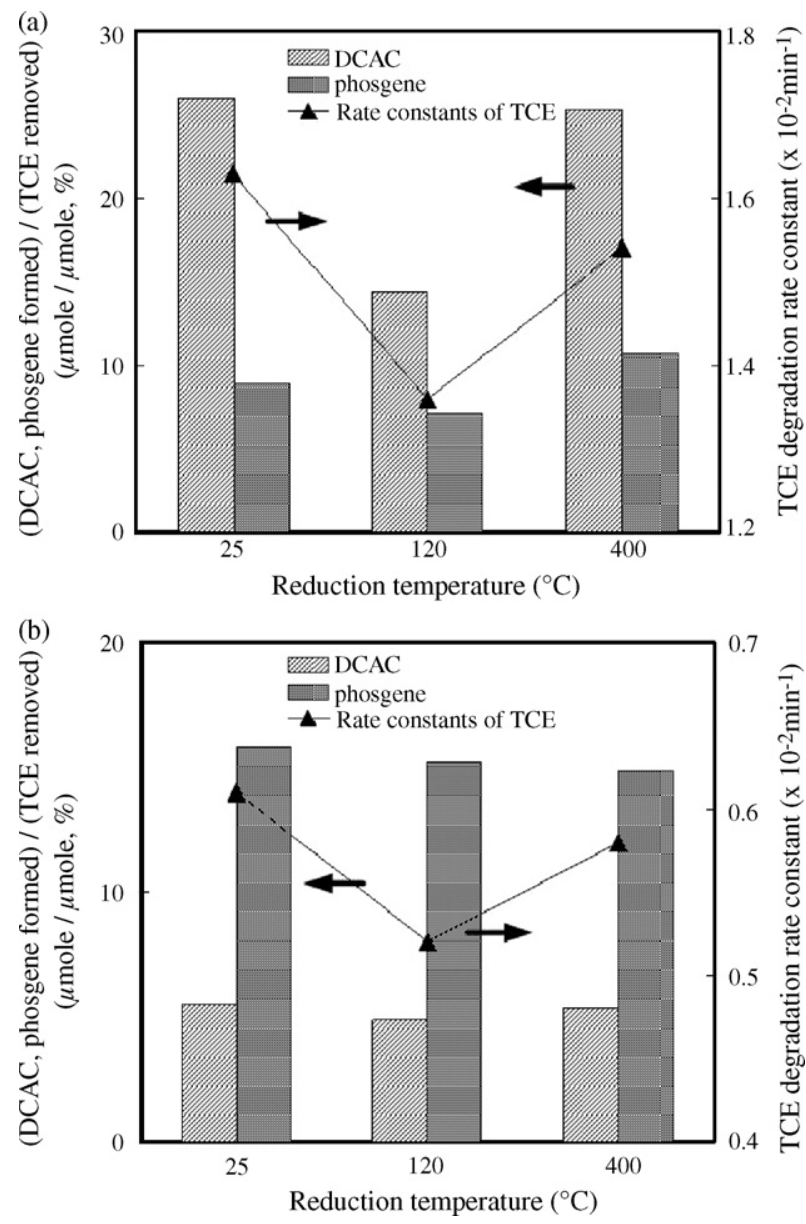

Fig. 6. The dependence of degradation rate constants of TCE, the yields of DCAC and phosgene on the reduction temperature of Pt/Pd species (a) $0.1 \mathrm{wt} . \%$ $\mathrm{Pt} / \mathrm{TiO}_{2}$ and (b) 0.04 wt. $\% \mathrm{Pd} / \mathrm{TiO}_{2}$.

0.1 wt. $\%$ Pt-doped $\mathrm{TiO}_{2}$ and 0.04 wt.\% Pd-doped $\mathrm{TiO}_{2}$ chosen for this measurement. Both $\mathrm{Pt} / \mathrm{Pd}$-doped $\mathrm{TiO}_{2}$ samples revealed the photocatalytic ability following the order of $25^{\circ} \mathrm{C} \fallingdotseq 400^{\circ} \mathrm{C}>120^{\circ} \mathrm{C}$ (Fig. 6). $\mathrm{Pt} / \mathrm{Pd}$-doped $\mathrm{TiO}_{2}$ reduced at $120^{\circ} \mathrm{C}$ presented the minimum $k_{\mathrm{obs}}$, which can be attributed to the existence of oxidation state of Pt/Pd (Fig. 4) because they provide an additional recombination center of irradiated electrons and holes [25]. Moreover, $\mathrm{Pt} / \mathrm{Pd}$-doped $\mathrm{TiO}_{2}$ reduced at 120 and $400^{\circ} \mathrm{C}$ were expected to possess lower $S_{\mathrm{BET}}$ than that of samples reduced at $25^{\circ} \mathrm{C}$. That explains why samples reduced at $25^{\circ} \mathrm{C}$ demonstrated the best performance on TCE degradation even though the oxidation state of $\mathrm{Pt} / \mathrm{Pd}$ was predominant in $\mathrm{Pt} / \mathrm{Pd}$-doped $\mathrm{TiO}_{2}$. Regarding the effect of oxidation state of $\mathrm{Pt} / \mathrm{Pd}$ on byproducts, the yields of DCAC and phosgene in the presence of $\mathrm{Pt}$ correspond to the degradation rate of TCE (Fig. 6(a)) while Pd had no influence on it (Fig. 6(b)). The related mechanism is discussed in the following section.

\subsubsection{The effects of Pt and Pd on the formation of DCAC and phosgene}

The effects of Pt and Pd on the yields of DCAC and phosgene are demonstrated in Fig. 5(a and b), respectively, where the yield is defined as the ratio of the peak production of DCAC 
and phosgene to the corresponding degraded TCE. As seen in Fig. 5(a), the yields of DCAC and phosgene in the presence of $\mathrm{Pt} / \mathrm{TiO}_{2}$ fell into the range of $10-30 \%$ and $4-12 \%$, respectively. The yields of DCAC and phosgene correspond to the $k_{\mathrm{obs}}$ of TCE. This indicates that the formation of DCAC and phosgene is subjected to the TCE degradation. The degradation mechanism of TCE over $\mathrm{Pt} / \mathrm{TiO}_{2}$ is likely to be the same as that of $\mathrm{P} 25$ $\mathrm{TiO}_{2}$. The phenomenon is consistent with the result provided by Driessen and Grassian [2], who reported that Pt particles were not involved in the photocatalytic oxidation of TCE on $\mathrm{Pt} / \mathrm{TiO}_{2}$. The overload of Pt just provides additional recombination centers or causes a shelter effect resulting in an inhibitory effect on the TCE degradation.

With increasing loading amount of $\mathrm{Pd}$ species, $\mathrm{Pd} / \mathrm{TiO}_{2}$ causes a significant decrease in the yield of DCAC to less than $6 \%$, and an increase in the yield of phosgene in the range of 8-16\% (Fig. 5(b)). The dependence of the yields of DCAC and phosgene on $\mathrm{Pd}$ shows an interesting phenomenon. Although the presence of $\mathrm{Pd}$ significantly retards the TCE degradation, it appreciably enhances the selectivity toward phosgene.

Regarding the mechanism of TCE degradation, the process involves chain reactions initiated by $\mathrm{Cl}^{\bullet}$ (Eq. (2)). $\mathrm{Cl}^{\bullet}$ is expected to react with $\mathrm{TCE}$ to form $\mathrm{CHCl}_{2} \mathrm{CCl}_{2}{ }^{\bullet}$, which immediately transforms to $\mathrm{CHCl}_{2} \mathrm{CCl}_{2} \mathrm{OO}^{\circ}$, as indicated in Eqs. (3) and (4), respectively. Reaction (5) demonstrates the well-known Russel mechanism of $\mathrm{CHCl}_{2} \mathrm{CCl}_{2} \mathrm{OO}^{\bullet}$, resulting in the formation of oxygenated hydrocarbon radicals, $\mathrm{CHCl}_{2} \mathrm{CCl}_{2} \mathrm{O}^{\bullet}[12,13]$. It has been confirmed that the selectivity toward DCAC or toward phosgene is dependent on the behavior of $\mathrm{CHCl}_{2} \mathrm{CCl}_{2} \mathrm{O}^{\bullet}$ (Eqs. (6) and (7)), an intermediate radical during TCE degradation.

$$
\begin{aligned}
& \mathrm{TiO}_{2}+h v \rightarrow \mathrm{e}^{-}+\mathrm{h}^{+} \\
& \mathrm{Cl}^{-}+\mathrm{h}^{+} \rightarrow \mathrm{Cl}^{\bullet} ; \quad \mathrm{O}_{2}+\mathrm{e}^{-} \rightarrow \mathrm{O}_{2}^{\bullet-} \\
& \mathrm{CHClCCl}_{2}(\mathrm{TCE})+\mathrm{Cl}^{\bullet} \rightarrow \mathrm{CHCl}_{2} \mathrm{CCl}_{2}{ }^{\bullet} \\
& \mathrm{CHCl}_{2} \mathrm{CCl}_{2}+\mathrm{O}_{2}^{\bullet-} \rightarrow \mathrm{CHCl}_{2} \mathrm{CCl}_{2} \mathrm{OO}^{\bullet} \\
& 2 \mathrm{CHCl}_{2} \mathrm{CCl}_{2} \mathrm{OO}^{\bullet} \rightarrow 2 \mathrm{CHCl}_{2} \mathrm{CCl}_{2} \mathrm{O}^{\bullet}+\mathrm{O}_{2} \\
& \mathrm{CHCl}_{2} \mathrm{CCl}_{2} \mathrm{O}^{\bullet} \rightarrow \mathrm{CHCl}_{2} \mathrm{CClO}(\mathrm{DCAC})+\mathrm{Cl}^{\bullet} \\
& \mathrm{CHCl}_{2} \mathrm{CCl}_{2} \mathrm{O}^{\bullet} \rightarrow \mathrm{CCl}_{2} \mathrm{O}(\text { Phosgene })+\mathrm{CHCl}_{2} \bullet
\end{aligned}
$$

As seen in reactions (6) and (7), the abstraction of the $\mathrm{Cl}$ atom from $\mathrm{CHCl}_{2} \mathrm{CCl}_{2} \mathrm{O}^{\bullet}$ results in the formation of DCAC while the cleavage of the $\mathrm{C}-\mathrm{C}$ bond causes the formation of phosgene $[6,12,16]$. Sanhueza et al. [6] discovered that $90 \%$ of degraded TCE would transform to DCAC. Based on the aforementioned results, it can be concluded that the participation of $\mathrm{Pd}$ is beneficial to the cleavage of the $\mathrm{C}-\mathrm{C}$ bond. Besides, the production of $\mathrm{H}_{2}$ and $\mathrm{CO}_{2}$ from oxygenated hydrocarbons in aqueous media involves the cleavage of $\mathrm{C}-\mathrm{C}$ bonds, $\mathrm{C}-\mathrm{H}$ bonds, and $\mathrm{O}-\mathrm{H}$ bonds. Mavrikakis and Barteau [26] have indicated that Pd particles are appropriate for these cleavages. This may be the reason for the increase in the selectivity to phosgene in the presence of $\mathrm{Pd}$. In this regard, the intercalated $\mathrm{Pd}$ species make the cleavage of $\mathrm{C}-\mathrm{C}$ bond within $\mathrm{CHCl}_{2} \mathrm{CCl}_{2} \mathrm{O}^{\bullet}$ easier, even though the bond energy of $\mathrm{C}-\mathrm{C}(83 \mathrm{kcal} / \mathrm{mol})$ is somewhat higher than that of $\mathrm{C}-\mathrm{Cl}(81 \mathrm{kcal} / \mathrm{mol})$, as demonstrated in Scheme 1.

\section{Conclusion}

Pt- and Pd-doped $\mathrm{TiO}_{2}$ were fabricated to investigate the effect of Pt and Pd species on the TCE degradation and on the yields of DCAC and phosgene. Some conclusions obtained from the experimental results are as follows:

1. Both $\mathrm{Pt}$ and $\mathrm{Pd}$ doped on $\mathrm{TiO}_{2}$ deliver an inhibitory effect on TCE degradation. Especially $\mathrm{Pd}$ doped on $\mathrm{TiO}_{2}$ dramatically retards photocatalytic efficiency owing to the intercalation of $\mathrm{Pd}$ into the $\mathrm{TiO}_{2}$ lattice.

2. The concentration of surface $\mathrm{OH}$ is irrelevant to TCE degradation, suggesting that $\mathrm{OH}^{\bullet}$ is not responsible for TCE degradation. Instead, $\mathrm{Cl}^{\bullet}$ initiates the photocatalysis of TCE.

3. $\mathrm{Pd}$ particles enhance the cleavage of $\mathrm{C}-\mathrm{C}$ bond rather than $\mathrm{C}-\mathrm{Cl}$ bond within $\mathrm{CHCl}_{2} \mathrm{CCl}_{2} \mathrm{O}^{\bullet}$, being favorable to forming phosgene compared to $\mathrm{Pt}$ particles.

4. In terms of the photocatalytic degradation of TCE, the photocatalytic behavior of Pt-doped $\mathrm{TiO}_{2}$ is the same as that of P25 $\mathrm{TiO}_{2}$, whereas Pd-doped $\mathrm{TiO}_{2}$ shows a different one.

\section{References}

[1] A. Linsebigler, C. Rusu, J.T. Yate, J. Am. Chem. Soc. 118 (1996) 5284.

[2] M.D. Driessen, V.H. Grassian, J. Phys. Chem. B 102 (1998) 1418.

[3] S.E. Park, H. Joo, J.W. Kang, Sol. Energy Mater. Sol. Cells 83 (2004) 39.

[4] T. Tanimura, A. Yoshida, S. Yamazaki, Appl. Catal. B: Environ. 61 (2005) 346.

[5] L.A. Dibble, G.B. Raupp, Catal. Lett. 4 (1990) 345.

[6] E. Sanhueza, K. Itoh, M. Murabayashi, Chem. Rev. 76 (1998) 313.

[7] M.R. Nimlos, W.A. Jacoby, D.M. Blake, T.A. Mllne, Environ. Sci. Technol. 27 (1993) 732.

[8] W.A. Jacoby, M.R. Nimlos, D.M. Blake, Environ. Sci. Technol. 28 (1994) 1661.

[9] H. Liu, S. Cheng, J. Zhang, C. Cao, Chemosphere 35 (1997) 2881.

[10] K.H. Wang, H.H. Tsai, Y.H. Hsieh, Chemosphere 36 (1998) 2763.

[11] J.S. Kim, H.K. Joo, T.K. Lee, K. Itoh, M. Murabayashi, J. Catal. 194 (2000) 484.

[12] P.B. Amama, K. Itoh, M. Murabayashi, Appl. Catal. B: Environ. 37 (2002) 321.

[13] P.B. Amama, K. Itoh, M. Murabayashi, J. Mol. Catal. A: Chem. 217 (2004) 109.

[14] M. Kang, J.H. Lee, S.H. Lee, C.H. Chung, K.J. Yoon, K. Ogino, S. Miyata, S.J. Choung, J. Mol. Catal. A: Chem. 193 (2003) 273.

[15] T.K. Lim, S.D. Kim, Chemosphere 54 (2004) 305.

[16] M. Mohseni, Chemosphere 59 (2005) 335.

[17] H.H. Ou, S.L. Lo, J. Hazard. Mater. 146 (2007) 302-308.

[18] J.C. Yu, J. Yu, J. Zhao, Appl. Catal. B: Environ. 36 (2002) 31.

[19] F.B. Li, X.Z. Li, Chemosphere 48 (2002) 1103.

[20] Y. Takasu, R. Unwin, B. Tesche, A.M. Bradshaw, Sur. Sci. 77 (1978) 219.

[21] S.C. Fung, J. Catal. 76 (1982) 225.

[22] D.C. Lee, J.H. Kim, W.J. Kim, J.H. Kang, S.H. Moon, Appl. Catal. A: Gen. 244 (2003) 83.

[23] J. Fan, J. Yates, J. Am. Chem. Soc. 118 (1996) 4686.

[24] W. Li, S. Ismat Shah, C.P. Huang, O. Jung, C. Ni, Mater. Sci. Eng. B 96 (2002) 247.

[25] J. Lee, W. Choi, J. Phys. Chem. B 109 (2005) 7399.

[26] M. Mavrikakis, M.A. Barteau, J. Mol. Catal. A: Chem. 131 (1998) 135. 